Idan Shimony

\title{
Kant on the Peculiarity of the Human Understanding and the Antinomy of the Teleological Power of Judgment
}

Kant argues in the Critique of the Teleological Power of Judgment that the first step in resolving the problem of teleology is conceiving it correctly. He explains that the conflict between mechanism and teleology, properly conceived, is an antinomy of the power of judgment in its reflective use regarding regulative maxims, and not an antinomy of the power of judgment in its determining use regarding constitutive principles. The matter in hand does not concern objective propositions regarding the possibility of objects or actual features of certain objects, namely, organisms. It is rather a methodological issue as to the appropriate way to explain the generation, development, and function of organisms. ${ }^{1}$ Taken in this manner as subjective maxims guiding the explanation and inquiry of organisms, the principles of mechanism and teleology need not necessarily be seen as contradictorily opposed but instead can be combined in the study of organisms. This, however, is not enough to complete the analysis of the antinomy of the teleological power of judgment. In order to show that there is an antinomy in this case, Kant has to establish that both seemingly conflicting maxims are necessary and natural to the human mind. ${ }^{2}$ He does it by grounding them in

Idan Shimony, Tel Aviv University, idanshimony@yahoo.com

1 Thus, the maxim of mechanism (the thesis) asserts that all material objects are to be explained purely mechanically, and the maxim of teleology (the antithesis) asserts that explanations of some material objects cannot rest merely on mechanical principles but must appeal to final causes.

2 Accordingly, transforming mechanism and teleology into regulative maxims of the reflective power of judgment is not enough for the completion of the discussion of the antinomy of the teleological power of judgment. As the title of $\S 71$ indicates, this move is only a 'preparation' (Vorbereitung) for the resolution of the teleological antinomy. This point has been noted by several commentators: McFarland, John: Kant's Concept of Teleology. Edinburgh 1970, 120 f.; Zumbach, Clark: The Transcendent Science: Kant's Conception of Biological Methodology. The Hague 1984, 142, n. 23; McLaughlin, Peter: Kant's Critique of Teleology in Biological Explanation: Antinomy and Teleology. Lewiston 1990, 137-140; Allison, Henry: Kant's Antinomy of Teleological Judgment. In: Southern Journal of Philosophy, Supplement 30 (1991), 25-42, 25, 29-30, 39 (n. 1); Grene, Marjorie and Depew, David: The Philosophy of Biology: An Episodic History. Cambridge 2004, 112-114; Ginsborg, Hannah: Two Kinds of Mechanical Inexplicability in Kant and Aristotle. In: Journal of the History of Philosophy, 42 (2004), 33-65, 36, n. 5; Guyer, Paul: Kant. London 
the 'special character' or peculiarity (Eigentümlichkeit) of the human understanding.

However, it is not entirely clear just what exactly this peculiarity of the human understanding is. Paul Guyer argues that Kant suggests two different accounts of the peculiarity of the human intellect. According to one account, this peculiarity consists in the fact that our understanding forms general concepts and according to another, in its propensity to proceed from the parts to the whole. I will argue in this paper that Kant puts forward a single account, in which the combination of these two features demonstrate the peculiarity of the human understanding manifested in the encounter with organisms. This account explains the necessity of the regulative maxims of mechanism and teleology, ${ }^{3}$ and thus completes Kant's analysis of the antinomy of the teleological power of judgment.

\section{The Two-Account Interpretation}

Guyer maintains that sections 76 and 77 of the Critique of the Power of Judgment contain two different accounts of the special character of the human understanding impeding a satisfactory comprehension of organisms. Consequently, commentators, focusing either on the one or on the other, suggest different accounts of the peculiarity of the human intellect and of the antinomy of the teleological power of judgment as a whole. ${ }^{4}$

According to Guyer, in $\S 76$ the peculiarity of the human understanding is expressed in the fact that it forms general concepts which cannot fully detail all the properties of particular objects. The problem with an argument based on this feature of the human understanding is that it seems to simply echo the general argument of the introduction to the third Critique and, therefore, undermines the special status of teleology. As Guyer explains, "while the inability of our general concepts to explain every property of a particular may be especially salient in

2006, 346; Geiger, Ido. Is Teleological Judgment (Still) Necessary? In: British Journal for the History of Philosophy, 17 (2009), 533-566, $546 \mathrm{f}$.

3 Note that the maxims of mechanism and teleology, although necessary, are regulative and not constitutive, since they are not necessary for experience as such or for experiencing objects, but only for organizing our experience, namely, for our quest to explain and construct systematic theories of natural phenomena.

4 Guyer (Kant, 410, n. 12) assigns to Henry Allison the account based on $\S 76$ and to Peter McLaughlin the account based on $\S 77$. See Allison: Kant's Antinomy of Teleological Judgment, 34-37; McLaughlin: Kant’s Critique of Teleology, 169-176. 
our experience of organisms, surely this general principle is true for every phenomenon in nature". 5

On the other hand, according to Guyer's interpretation in $\S 77$ the peculiarity of the human understanding is taken to be its propensity to construct explanations by moving from the properties of the parts to the whole explained thing. An argument based on this feature of the human understanding depends on the analysis of organisms in the Analytic of the Teleological Power of Judgment. In the Analytic, Kant argues that certain functions and features of organisms cannot be explained solely by means of the action of their parts. ${ }^{6}$ But such an argument, Guyer contends, runs counter the progress of modern biology, which "consists in the increasing ability to explain how organisms function to preserve and reproduce themselves by means of the specific actions of their parts". 7

\section{An Alternative Interpretation}

In contrast to Guyer, I suggest that Kant puts forward a single argument. On my reading, these two features of proceeding from universal concepts to particular things and from parts to wholes are intimately connected and incorporated in a unified argument presenting a peculiarity of the human understanding coming into play in its encounter with organisms. As we shall see, this reading also serves to mitigate some of the difficulties that Guyer finds in Kant's analysis of teleology.

In the first place, consistent with his position in the Critique of Pure Reason, Kant emphasizes again in the third Critique that the human understanding is a discursive intellect or a faculty of concepts. That is to say, it proceeds from universal concepts to particular things given in intuition, or more specifically, by subsuming particular things under general concepts and principles. We conceptualize particular phenomena by means of the concepts and principles of the understanding. Put differently, a concept of a particular phenomenon maps the parts and features of that phenomenon. The concept, however, provides only a limited layout of the intuited particular. Our concepts suffice to identify objects

5 Guyer: Kant, 345.

6 For an analysis of Kant's argument in the Analytic of the Teleological Power of Judgment, see Shimony, Idan: The Antinomies and Kant's Conception of Nature. Tel Aviv 2013, 192-199.

7 Guyer: Kant, 345. For a reply to Guyer's criticism of Kant's view of biology, see Shimony, Idan: What Was Kant's Contribution to the Understanding of Biology? In: Kant Yearbook, 9 (2017), 159178. 
in certain circumstances and to describe some features and behaviors of objects, but they never fully grasp the entire concrete particularity of individual phenomena. Even empirical concepts, which present a more detailed description of phenomena than the pure concepts of the understanding, do not provide a complete characterization. Kant expresses this by claiming that there is an element of contingency in the correspondence between our concept and the relevant particular. $^{8}$

Since our concepts only partially map objects, we always proceed from the parts mapped to the whole, which contains other features not yet explored. Indeed, this is a feature peculiar not only to human reason, but in general to "any finite reason that is similar to ours in quality". ${ }^{9}$ A finite reason proceeds from the incomplete knowledge of certain parts of the object to an investigation of other parts and the whole object. This feature of the human understanding is more crucial in the investigation of organisms than in studying inanimate phenomena. Our partial knowledge and characterizations of things do not, for the most part, prevent us from understanding inanimate phenomena. This is so because the parts and features that do figure into our characterizations of inanimate phenomena may suffice for the comprehension of how they come into being and how they evolve and function. ${ }^{10}$ On the other hand, when investigating living phenomena we cannot simply proceed from the parts to the whole, since, as Kant has shown in the Analytic, we regard living phenomena as things in which the parts and the whole reciprocally depend on one another. In this case, then, knowledge of the parts depends on knowledge of the whole. But since we never have an empirical characterization of the whole, in its entirety, an investigation of a given organism must proceed on the basis of a representation (Vorstellung) of the whole organism.

8 See Kant: KU, AA 05: 406.34-407.04: "Unser Verstand hat also das Eigene für die Urtheilskraft, daß im Erkenntniß durch denselben durch das Allgemeine das Besondere nicht bestimmt wird, und dieses also von jenem allein nicht abgeleitet werden kann; gleichwohl aber dieses besondere in der Mannigfaltigkeit der Natur zum Allgemeinen (durch Begriffe und Gesetze) zusammenstimmen soll, um darunter subsumirt werden zu können, welche Zusammenstimmung unter solchen Umständen sehr zufällig und für die Urtheilskraft ohne bestimmtes Princip sein muß." 9 Kant: KU, AA 05: 409.34-35: "keine endliche, die der Qualität nach der unsrigen ähnlich wäre”. All references to the Critique of the Power of Judgment are to the translation by Paul Guyer and Eric Matthews, Cambridge 2000.

10 See for instance Kant's favorite example of wind behavior in tropical coasts: Kant: NTH, AA 01: 223-225; TW, AA 01: 492-494; BDG, AA 02: $97 \mathrm{f}$. One need not have complete concepts of the air, sea, and land in these specific areas in order to explain this phenomenon. It suffices that one knows that the land heats up and cools down faster than the sea and how this fact influences the processes by which the density of various subsections of the air decreases and increases. 
The argument outlined here demonstrates that both regulative maxims of mechanism and teleology are necessary for the explanation of organisms due to the structure of the human understanding. This is essential for Kant's analysis of the antinomy of the teleological power of judgment, since an antinomy according to Kant is a conflict between principles which are necessary and natural to the human intellect. ${ }^{11}$ On the one hand, we must employ the maxim of mechanism, since due to the discursive character of our understanding we must explain things as the outcome of the properties and forces of their parts, which is just what it means to explain things mechanically. ${ }^{12}$ We must also employ the maxim of teleology, since when investigating a thing in which the parts and the whole reciprocally depend on one another, our inability to empirically grasp wholes forces us to appeal to a representation of the whole thing, which is just what it means to explain by means of final causality. ${ }^{13}$

since the whole would in that case be an effect (product) the representation of which would be regarded as the cause of its possibility, but the product of a cause whose determining ground is merely the representation of its effect is called an end, it follows that it is merely a consequence of the particular constitution of our understanding that we represent prod-

11 The antinomy of the teleological power of judgment is a conflict between necessary principles of reason, understood as the intellectual faculty in the broader sense: it is a conflict between two maxims of the reflective power of judgment, and not between, say, assertions contingently grounded on the imagination or the senses. Cf. Kant's explication of 'dialectic' in $\S 55$. 12 See Kant: KU, AA 05: 408.24-27: "Wenn wir nun ein Ganzes der Materie seiner Form nach als ein Product der Theile und ihrer Kräfte und Vermögen sich von selbst zu verbinden (andere Materien, die diese einander zuführen, hinzugedacht) betrachten: so stellen wir uns eine mechanische Erzeugungsart desselben vor." Kant: EEKU, AA 20: 236.01-04: "Da es nun ganz wider die Natur physisch-mechanischer Ursachen ist, daß das Ganze die Ursache der Möglichkeit der Caussalität der Theile sey, vielmehr diese vorher gegeben werden müssen, um die Möglichkeit eines Ganzen daraus zu begreifen".

13 These features may not be uniquely peculiar to the human understanding. As noted above, they may also be applicable to other finite understandings that are "similar to ours in quality". However, there is at least one conceivable understanding, to which these features do not apply, namely, an intuitive understanding. An intuitive understanding is not constrained to move from universals to particulars and from parts to wholes. It rather directly grasps the whole particular in its entirety. In its representation of the whole "there is no contingency in the combination of the parts, in order to make possible a determinate form of the whole" (Kant: KU, AA 05: 407.23-25: "dessen Vorstellung des Ganzen die Zufälligkeit der Verbindung der Theile nicht in sich enthält, um eine bestimmte Form des Ganzen möglich zu machen"). Allison (Kant's Antinomy of Teleological Judgment, 36f.) maintains that the point of Kant's contrast of our discursive understanding with an intuitive understanding is to stress that the peculiar manner in which we investigate organisms reflects a merely subjective necessity, and that it, therefore, cannot be taken as indicating anything with respect to things themselves. 
ucts of nature as possible only in accordance with another kind of causality than that of the natural laws of matter, namely only in accordance with that of ends and final causes. ${ }^{14}$

Kant's analysis of the special character of the human understanding thus shows that the regulative maxims of mechanism and teleology are necessary for the investigation of organisms. This means that in such investigations, we must find a way to combine the maxim of mechanism, which instructs us to explain objects in terms of the properties and forces of their parts, with the maxim of teleology, which instructs us to regard organisms as objects in which each part has an essential function in the whole and in which nothing is in vain. ${ }^{15}$ Kant maintains that the two should be combined in the following way: whenever we discern a purpose or function in an organism, we should mechanically investigate the means by which the function in question is served. This is what Kant means when he claims that the maxim of mechanism has to be 'subordinated' to that of teleology. ${ }^{16}$

\section{Implications and Conclusions}

The interpretation presented in this paper suggests a coherent and unified reading of Kant's text, one which does not break it into unconnected segments. Furthermore, it shows how the concluding sections of the Dialectic complete Kant's analysis of the antinomy of the teleological power of judgment by explaining why the regulative maxims of mechanism and teleology are necessary and naturally inhere in the human intellect. And most importantly, this interpretation resolves some of the difficulties that commentators find in Kant's discussion.

14 Kant: KU, AA 05: 408.02-10: "Da das Ganze nun aber alsdann eine Wirkung, Product, sein würde, dessen Vorstellung als die Ursache seiner Möglichkeit angesehen wird, das Product aber einer Ursache, deren Bestimmungsgrund bloß die Vorstellung ihrer Wirkung ist, ein Zweck heißt: so folgt daraus, daß es bloß eine Folge aus der besondern Beschaffenheit unseres Verstandes sei, wenn wir Produkte der Natur nach einer andern Art der Causalität, als der der Naturgesetze der Materie, nämlich nur nach der der Zwecke und Endursachen, uns als möglich vorstellen."

15 See Kant: KU, AA 05: 376.11-14: “ein organisirtes Product der Natur ist das, in welchem alles Zweck und wechselseitig auch Mittel ist. Nichts in ihm ist umsonst, zwecklos, oder einem blinden Naturmechanism zuzuschreiben.” Kant: KU, AA 05: 420.17-19: “in einem organisirten Wesen nichts von dem, was sich in der Fortpflanzung desselben erhält, als unzweckmäßig zu beurtheilen”.

16 See Kant: KU, AA 05: 414.12-27. 
First, on my reading the regulative maxim of mechanism requiring to explain from the parts to the whole is not an arbitrary supplement to the transcendental structure presented in the first Critique but rather depends on it. Kant does not introduce here, as Peter McLaughlin argues, a second peculiarity, ${ }^{17}$ one which is entirely different from the constitutive discursive peculiarity established in the first Critique and which, therefore, may seem to exhibit merely psychological subjective necessity. As we have seen, the requirement to mechanically explain from the parts to the whole is closely connected to the fundamental discursivity of the human intellect. Kant relies here on the original characterization of the human understanding in the first Critique: rather than arbitrarily adding a further feature to this characterization, he draws from it implications to our explanations of natural phenomena. Neither is the maxim of mechanism introduced into Kant's analysis simply due to the influence of the contemporary dominant mechanical philosophy. Whereas this might have been true in earlier writings such as the Universal Natural History and the Only Possible Argument, ${ }^{18}$ where the methodological instruction to extend the mechanical mode of explanation as far as possible seems to follow from an assumption as to what is more philosophical, in the third Critique Kant grounds this instruction in the peculiar nature of the human understanding. As Kant puts it, "In accordance with the constitution of our understanding [...] a real whole of nature is to be regarded only as the effect of the concurrent moving forces of the parts."19

In addition, my interpretation also brings to the fore the uniqueness of teleology and the peculiarity of the human understanding coming into play in this context. It elucidates why explaining organisms is different from explaining inanimate phenomena, and it does so in a way that is not dependent, as Guyer suggests, on arbitrary limitations placed on scientific explanations or on human psychological conditioning. ${ }^{20}$ Kant's requirement of teleological explanations in certain cases is not an empirical or a psychological observation but rather a fundamental conceptual point, which is part and parcel of his transcendental analysis of human cognition and knowledge. Since the human understanding is constituted so that it must proceed from the parts to the whole and not the other way around, in explaining things regarded as objects in which the parts and the

17 McLaughlin: Kant's Critique of Teleology, 171f.

18 See for example Kant: BDG, AA 02: 126f., 134-137.

19 Kant: KU, AA 05: 407.28-30: "Nach der Beschaffenheit unseres Verstandes ist [...] ein reales Ganze der Natur nur als Wirkung der concurrirenden bewegenden Kräfte der Theile anzusehen." 20 Guyer: Kant, 348f., 358. 
whole reciprocally depend on one another, it must appeal to a representation of the whole and thus to final causality.

Now whether organisms are in actual fact things that we must teleologically explain is an open question. In contrast to what is implied in Guyer's discussion, there is no consensus among biologists and philosophers of biology regarding this question. Eminent figures in these fields still think that organisms display unique features and that biology is not reducible to physico-mechanical explanations. ${ }^{21}$ In any case, the crucial thing is that Kant's discussion presents a point of principle. The human intellect is constituted to form mechanical explanations and therefore may fail in providing satisfactory explanations of objects which do not readily lend themselves to this type of explanation. At the very least, organisms draw our awareness to the fact that there is no a priori guarantee that all the objects we ever come to cognize will fit the mechanical type of explanation. Accordingly, it may be more fitting to read the teleological maxim as follows. Instead of literally reading it as asserting that 'some products of material nature' (einige Producte der materiellen Natur) cannot be explained purely mechanically and an appeal must be made to final causes in order to explain them, one should read it as claiming that some possible material objects may not be explained purely mechanically and an appeal must be made to final causes in order to explain them. It is the empirical encounter with organisms that draws our attention to this possibility, and thereby leads us to the teleological maxim. But again, although this empirical encounter with organisms leads us to the teleological maxim, it does not make the maxim itself empirical or merely psychologically necessary. As Kant clearly explains, the necessity that this maxim embodies "cannot rest merely on grounds in experience, but must have as its ground some sort of a priori principle".22

21 See for example Mayr, Ernst: What Makes Biology Unique? New York 2004; Ayala, Francisco: Evolution and the Autonomy of Biology. In: Aquinas, 43 (2000), 283-312.

22 Kant: KU, AA 05: 376.18-22: "kann es nicht bloß auf Erfahrungsgründen beruhen, sondern muß irgend ein Princip a priori [...] zum Grunde haben”. 